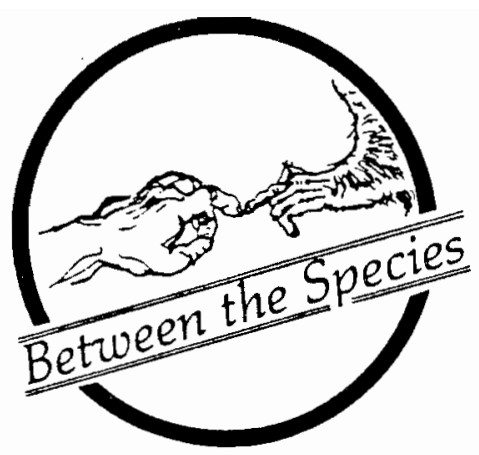

\title{
MIXING WITHOUT PAIN
}

Jim Harter, Animals: 1419 Copyright-Free Illustracions. New York: Dover, 1979

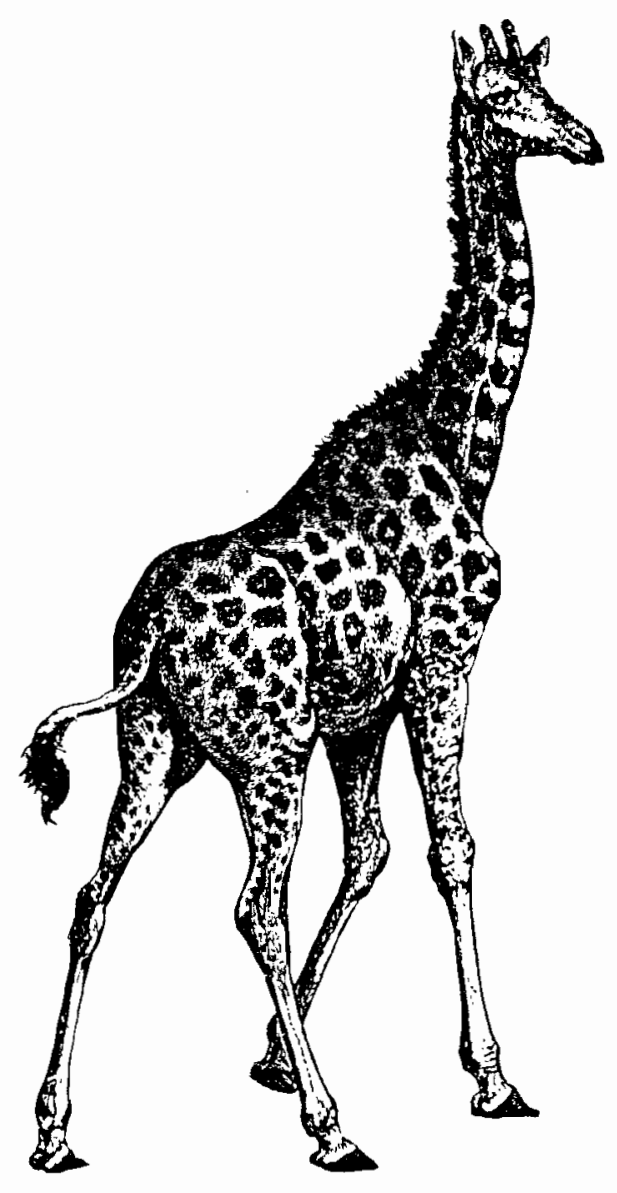

Karen Davis

The University of Maryland College Park

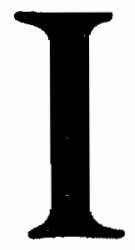

am a deep ecologist. I value Nature for its own sake. I see other, nonhuman beings as subjects of an infinitely precious and unique life, as wanting and able to live their own lives, and as having the right to do so, just as we do ourselves. I relish John Muir's thought that "even a mineral arrangement of matter [may] be endowed with sensation of a kind that we in our blind exclusive perfection can have no manner of communication with." 1 Like Aldo Leopold, I yearn for the day when the role of Homo sapiens will have changed "from conqueror of the land-community to plain member and citizen of it."2 I share Arne Naess's passion for an ecological maturity that

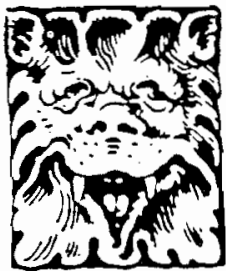

COMMENT 
will allow people to "experience joy when other life forms experience joy and sorrow when other life forms experience sorrow," that will enable us to "grieve when living beings, including landscapes, are destroyed." I I do not have to be convinced that wilderness and wildlife have a right to exist or that what is needed nowadays, ecologically, is not so much "hands-on experience" as "hands-off." I reject the assertion of human superiority over other life. I take the fact of my belonging to an animal species as basic to my existence and my experience.

I am also an animal rights person. I believe that human and nonhuman animals both have rights. I think that animal liberation is human liberation, and vice versa. I share John Bryant's dream in Fettered Kingdoms of finding "a place where humans, trees, water and wildlife mix without pain" and of creating "a world of peace, where we could walk amongst the other creatures of this planet without them fleeing in panic at the merest whiff of human scent." 4 Does our dream make John Bryant and me sound more like shallow sentimentalists than deep ecologists?

In their book Deep Ecology, George Sessions and Bill Devall define deep ecology as "a way of developing a new balance and harmony between individuals, communities, and all of Nature." 5 An essential part of this way, said Arne Naess, coiner of the term deep ecology, is "to ask deeper questions." $\mathrm{My}$ question has to do with the deep ecology movement's macho mystique. I wonder to what extent deep ecology is an ecological disguise for machismo fantasies. I find that being an animal rights person gets in the road of my being a deep ecologist. I find that being a woman also gets in the road. It's the nature of the consciousness that's obstructive.

I mistrust a philosophy that cannot imagine a human future without violence in it and seems frankly to fight shy of the whole idea of such a future. I mistrust an ecovision that encourages disdain for the weak and helpless creatures of the world - the "genetic goofies"? and "man-made freaks" such as farm animals and other domesticated members of Earth's community. Violence sanctified by Myth is no more acceptable to me than violence rationalized in terms of the scientific Model. The fact that the Myth is "encompassing, intuitive, comforting, involving," whereas the Model is "limited, cold, manipulative, distant from reality" does not solve the problem. ${ }^{8}$ For the unconsenting victim of Myth or Model, these distinctions are moot. Violence directed against nonhuman animals is recommended by Sessions and Devall as "a way to encourage maturity" if done with the "proper attitude." Hunting and fishing, they say, can enable us to develop "a sense of place and intuitive understanding of the connections between humans and nonhumans together with a respect for the principle of biocentric equality" as this principle has been laid down by ecotopian philosophers Aldo Leopold and Arne Naess. ${ }^{9}$ I do not think, though, that any of these men have me, a woman, in mind for this sanguinary discipline. Rather, they sound like men talking as usual to other men.

A few years ago, ecoholist philosopher J. Baird Callicott write an article which prototypically asserts that the concept of animal liberation conflicts not only with the anthropocentric assumptions of Western moral philosophy, but with the biocentric assumptions of modern environmental ethics as characterized in Aldo Leopold's "land ethic."10 Far from prohibiting human predatory activities such as hunting, fishing, and meat-eating, the land ethic vigorously promotes these things if done 
with the, as it were, "proper attitude." Unlike John Muir, who neither hunted nor fished and who considered the human desire for animal flesh a "depraved appetite,"11 Leopold was an avid hunter who "did not see that his land ethic actually ought to prohibit hunting, cruelly killing, and eating animals." 12

A moral theory of the environment, based upon Leopold, could thus be advanced that would regard nonhuman animals as beings "to whom ethical consideration is owed and yet not object to some of them being slaughtered (whether painlessly or not) and eaten, others hunted, trapped, and in various other ways seemingly cruelly used." 13 A salutary type of humanity would be one which relished the chase, ate animal flesh with "respect," and which cultivated a healthy tolerance for (others'?) pain. Although modern society could not be expected to recrudesce the Stone-Age ethos in its pristine form, still this ethos might be not inelegantly adapted by future human societies seeking a more direct contact with Nature than what we in Western culture now have. 14

Here in a nutshell is the ecotopian vision to which the deep ecology core constituency seems essentially to subscribe. Moral and cultural simplicity are equated with an ersatz primitivism. Courage and relish thrive on ritual pain and death. There does seem to be a limit, though, as to just how far into the wilderness Ecotopian Man is willing to go. So far I know of no deep ecologist, no ecoholist, who advocates, as a way to ecological maturity and "identification with all life," 15 acting the part of the hunted in a hunt. Deep ecologist Dave Foreman's desideratum that his dead body shall be food for carrion, not pickled in a lead coffin, dodges the question of how he would care to die. ${ }^{16}$ In fact, the role of humans in the sacred chase is pre- sumed as a matter of course in deep ecology discourse to be that of hunters. Yet why must this be so? After all, shouldn't being hunted, and what it feels like to be hunted, be counted as an authentic part of the wilderness experience? By what appeal do we deny this part to ourselves? It may be replied that the human being in the role of hunted animal runs contrary to Nature. Humans hunt; they are not hunted, except by noxious insects. Still, we may ask with John Muir, "How about those man-eating animals lions, tigers, alligators - which smack their lips over raw man?"17

For refusing to inflict pain and death on his "earth-born companions and fellow mortals" of the woods and streams, ${ }^{18}$ Muir was patronized by his otherwise admiring, deep ecologyminded biographer Michael P. Cohen, who writes in The Pathless Way that Muir "was never aware of the significant bond forged between hunter and hunted, when a man became a part of the flow of energy in Nature." In Cohen's estimate, Muir lacked "insight into violence." By contrast, Aldo Leopold's interest in hunting may have made him more sophisticatedly savvy "of the role of predators in ecological communities." Muir, though, "despite frequent contact with Indian culture ... did not think about hunting as an enlightening activity." 19 No, he did not. One reason is that Muir had insight into human violence. He recognized the "indivisibility of violence." ${ }^{20}$ Muir wrote: "From the shepherd with his lambs to the red-handed hunter, it is the same; no recognition of rights - only murder in one form or another."21

An article in Defenders magazine throws a lurid light on hunting as "an enlightening activity" in Indian culture. It says that "The Indians' favorite method of bear hunting was to force a bear out of its den with flaming 
torches." 22 Is this the sort of thing Bill Devall has in mind when he opines that "For at least forty thousand years, humans have hunted bears, yet in primal societies bears were treated with respect and honor due a god"?23 What kind of a god? The Dionysian god whose fate was ritually symbolized in tribal ceremonies in which humans and nonhumans were "honored" by being torn to pieces? Shall we resurrect an ersatz version of that drama? Where should atavistic recrudescence stop? Why should it stop, if it brings us closer to "Nature" and allows us to renew the sensations of our Mythic Past?

Wild animals have an honorific status in deep ecology. What about domesticated animals? What do deep ecologists say is our responsibility towards animals whose lives have been as foully wrecked by human deformative practices as the lives of ecosystems? Does the "bovine mind" of which Susan Griffin speaks so eloquently and compassionately have a role in deep ecology?24 Is there an ethical niche for chickens? A place where sheep may safely graze? Somewhere for feral pigs to roam unmolested as "pests"? 25 How ominous for the future of the movement, and for all these animals, is the fact that Aldo Leopold never seems to have considered "the treatment of brood hens on a factory farm or steers in a feed lot to be a pressing moral issue"? ${ }^{26}$ Will deep ecologists follow in Aldo Leopold's tracks? Should women follow in his tracks? If we heed Constantina Salamone, the answer is No. She asks: "Was woman, gentled aged guardian of the smaller creatures, really a Diana, the huntress, of the classical (male) mythology?" 27 Ostensibly this question concerns the past. Its true purport, however, is to address the present and the future. Whatever women have been - and like men we seem to have run the gamut in our roles - we can shape ourselves into something new. We can become ecopersons. Together with gentle men we can be a voice not only for Life but for lives - for all the soft and innocent lives who are at our mercy.

To be this kind of a voice requires us to reconcile the rights of animals and the rights of wilderness, the preciousness of individuals and communities, as Karen DeBraal and Susan Finsen have said that we might if we commit our hearts and minds to the effort. ${ }^{2 B}$ As ecopersons, we can seek diligently for ways to mix with other lives without bringing them pain. ${ }^{29}$ "Squalling life, animal and human, announces itself at our mercy." 30 Are we listening? What answer shall we give?

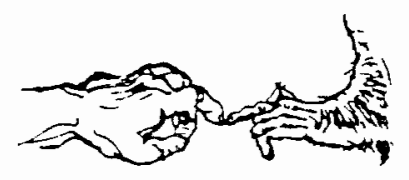
SOCIETY FOR THE STUDY OF ETHICS AND ANIMALS Call for Papers
for
Pacific Division Meeting
(in conjunction with American Philosophical Association) Southern California March, 1990

Papers on any topic impacting ethical issues concerning nonhuman animals are welcome. Possible topics include:

The moral (in)significance of being natural (as opposed to domesticated or genetically engineered).

Are Animal Liberation Front activities consonant with an animal rights ethic?

Historical studies of conceptions of the moral standing of animals. Papers must be double-spaced and be ten to fifteen pages in length. Those interested in submitting papers should make their intention, along with an indication of the projected topic known as soon as that is possible. Final papers, or substantive drafts, must be received by September 15, 1989. Send statements of intent end papers to:

Professor Steve F. Sapontris Department of Philosophy California State University Hayward, California 94542

Those interested in chairing the session or in being commentators should also contact Prof. Saponzis by September 15.

(Papers and comments will subsequently be published in Between the Species.) 


\section{Notes}

1 John Muir, The Wilderness World of John Muir, ed. Edwin Way Teele (Boston: Houghton Mifflin 1954), p. 317.

2 Aldo Leopold, A Sand County Almanac (New York: Ballantine 1970), p. 240.

3 Quoted in Bill Devall and George Sessions, Deep Ecology: Living as if Nature Mattered (Salt Lake City: Gibbs M. Smith 1985), p. 75.

4 John Bryant, Fettered Kingdoms: An Examination of a Changing Ethic (n.p. 1982), p. 5.

${ }^{5}$ Devall and Sessions, p. 7.

${ }^{6}$ Quoted in Devall and Sessions, p. 74.

7 Paul Shepard's term for domestic plants and animals, quoted in Devall and Sessions, p. 172.

8 Devall and Sessions, p. 151.

${ }^{9}$ Devall and Sessions, p. 188.

10 J. Baird Callicotr, "Animal Liberation: A Triangular Affair," Environmental Echics 2 (1980): 311. 38.

11 Quoted in Michael P. Cohen, The Pathless Way: John Muir and American Wildemess (Madison: The University of Wisconsin Press 1984), p. 182.

12 Callicott, p. 314.

13 Callicott, p. 319-20.

14 Callicott, p. 334.

15 Devall and Sessions, p. 187.

16 Wayne Pacelle, "The Foreman of Radical Environmentalism: A Discussion with David Foreman of Earth First!" The Animals' Agenda December 1987: 9.

17 Muir, p. 316.

18 Muir, p. 317.

19 Cohen, p. 184.

20 Jon Wynne-Tyson's phrase, quoted in Victoria Moran, Compassion, The Ulimate Ethic: An Exploration of Veganism (Wellingborough, Northamptonshire: Thorsons Publishers Limited 1985), p. 35.

21 Muir, p. 302.

22 Chris Bolgiano, "Do Appalachia's Bears Have a Future?" Defenders Nov./Dec. 1987: 21.
23 Bill Devall, rev. of The Sacred Paw: The Bear in Nature, Myth, and Literature, by Paul Shepard and Barry Sanders, Earth First! 20 March 1986: 26.

24 Susan Griffin, Woman and Nature: The Roaring Inside Her (New York: Harper \& Row 1978), p. 67.

25 Karen DeBraal's plea for consideration of the rights of feral pigs in "Animal Rights Vs. The Wilderness," Earth First! 1 May 1986: 21, is followed by an Editor's Note to an adjacent article, advising hunters to "hunt 'pest' species such as feral pigs, starlings, Norway rats, grasshoppers, or locusts." The Note also advises meat-eaters to "Poach public lands cattle and sheep." No doubt wild nonhuman predators would be the ones who would bear the blame and punishment for depleted livestock, if the latter advice were followed.

26 Callicott, p. 314.

27 Constantina Salamone, "The Prevalence of the Natural Law Within Women: Women and Animal Rights," Reweaving the Web of Life: Feminism and Nonviolence, ed. Pam McAllister (Philadelphia: New Society Publishers 1982), p. 369.

28 See n. 25, above. Also see Susan Finsen, "Making Ends Meet: Reconciling Ecoholism and Animal Rights Individualism," Between the Species 4 (1988): 11-20.

29 I do not mean by this that human beings have either the obligation or the right to stop wild predators from pursuing their own evolutionary course and fulfilling their own telos. While the utilitarian-based Animal Liberation ethic may logically justify such action in the interest of reducing the amount of pain and suffering in the world, the Animal Rights ethic does not, however much we each may dream of the day when the lion and the lamb shall lie down together in peace. Animal Rights recognizes, and works for, the right of nonhuman animals to live their own lives and, in the words of Ingrid Newkirk of People for the Ethical Treatment of Animals, "possess their own dignity." Animal Rights (Clarks Summit, PA: International Society for Animal Rights, Inc. 1987), pp. 184-97.

${ }^{30}$ Salamone, p. 369. 